\title{
Mezopórusos szol-gél bevonatok: előállítás, jellemzés, alkalmazás ${ }^{\dagger}$
}

\author{
ALBERT Emőke* és HÓRVÖLGYI Zoltán \\ Budapesti Müszaki és Gazdaságtudományi Egyetem, Vegyészmérnöki és Biomérnöki Kar, \\ Fizikai Kémia és Anyagtudományi Tanszék, Budafoki út 6-8., 1111 Budapest, Magyarország
}

\section{Bevezetés}

Számos technológiai alkalmazás területén egyre nagyobb igény mutatkozik tervezett felületi tulajdonságokkal rendelkező, speciális igényeknek eleget tevő anyagok kialakítására. Ennek egyik lehetséges módja funkcionális felületek kialakítása a felületek bevonatokkal való ellátása révén. A nanoszerkezetü bevonatok alkalmazásával a felületek új és kedvező tulajdonságokkal láthatók el, a hordozó előnyös sajátságainak megörzése mellett. Viszonylag kis anyagmennyiségek felhasználásával elönyös optikai, mechanikai, mágneses, fotokatalitikus, fotovoltaikus, elektromos, tapadásgátló, korróziógátló, ${ }^{1,2}$ víztaszító, ${ }^{3}$ antibakteriális, ${ }^{4,5}$ öntisztuló, stb. tulajdonságok alakíthatók ki különböző szilárd hordozókon a bevonatok létrehozásával. A nedveskémiai eljárások közé tartozó szol-gél módszer nagy előnye, hogy az anyag tulajdonságai a kísérleti paraméterek módosításával befolyásolhatók, ezáltal széles határok között, tervezetten változtatható a kialakítandó termékek szerkezete, morfológiája és egyéb tulajdonságai. ${ }^{6}$ A vékonyrétegek elönyös tulajdonságai a bevonat anyagának sajátságai mellett sok esetben azok nanostrukturált jellegéből adódnak. Megfelelő felületi szerkezetek kialakítása révén pl. szabályozható a felületek nedvesíthetősége (szuperhidrofób felületek), vagy megakadályozható a baktériumok megtapadása, szaporodása az adott felületen. Mezopórusos vékonyrétegek pórusrendszere pedig kiválóan alkalmazható pl. különböző nanorészecskék, korróziós inhibitorok, vagy gyógyszerhatóanyagok molekuláinak tároló-, szállító- és leadó-rendszereként. ${ }^{7,8}$

A kutatómunka ${ }^{9}$ során különböző alkalmazási területek szempontjából előnyös tulajdonságú mezopórusos és (esetenként, összehasonlítás céljából) kompakt szol-gél bevonatokkal foglalkoztunk. A pórusrendszert Pluronic PE 10300 (Pluronic) nemionos, és cetil-trimetilammónium-bromid $(C T A B)$ kationos felületaktív anyagok felhasználásával alakítottuk ki. A jellemzően néhány száz nanométer vastagságú bevonatokat a mártásos szol-gél technikával hoztuk létre különböző anyagú szilárd hordozók felületén. A kialakított és tanulmányozott bevonattípusok a célzott funkciók, illetve tulajdonságok szerint három csoportba sorolhatók.

Antibakteriális tulajdonság kialakítására ezüsttartalmú $\mathrm{TiO}_{2}$-bevonatokat képeztünk üveghordozókon. Vizsgáltuk a hosszú távú antibakteriális hatás és a kialakított kompozit bevonatok szerkezete, az ezüstadalékolás módja, valamint a kialakuló ezüst nanorészecskék mérete és mennyisége közötti összefüggéseket. ${ }^{10}$

Korróziógátló felületeket $\mathrm{SiO}_{2}$-bevonatok kialakításával hoztunk létre cink-lemezek felületén. Tanulmányoztuk a védőbevonatok kompakt, vagy pórusos mivoltának, a rétegvastagságnak, porozitásnak, a pórusok rendezett, vagy rendezetlen jellegének és a felület hidrofobitásának a bevonatok permeabilitására, ezáltal a korrózió elleni védelem mértékére gyakorolt hatását. Emellett modellvizsgálatokat végeztünk arra vonatkozóan is, hogy a bevonatok pórusrendszere alkalmas-e korróziós inhibitormolekulák felvételére, tárolására és szabályozott leadására. ${ }^{11,12}$

Periodikus felületi morfológiával rendelkező, mezopórusos $\mathrm{SiO}_{2}$-bevonatokat $\mathrm{Si}$ hordozókon alakítottunk ki. Ilyen szerkezetek mind az antibakteriális, mind a korróziógátló bevonatok területén, illetve további funkcionális felületek kialakítása során nyerhetnek jelentőséget. A felületi struktúrákat a nanogömb litográfia és az ionbesugárzás együttes alkalmazásával hoztuk létre, az átjárható pórusrendszert megőrizve, vagy egymástól kompakt régiók által elkülönített pórusos tartományokat kialakítva. Vizsgálatainkat kiterjesztettük egy, az eddigi munkákban figyelmen kívül hagyott összefüggés, a pórusrendszer eredeti (rendezetlen vagy rendezett) jellege és az ionbesugárzás hatására kialakuló szerkezet közötti kapcsolat tanulmányozására. ${ }^{13}$

\section{Eredmények}

\subsection{Antibakteriális hatású $\mathrm{Ag} / \mathrm{TiO}_{2}$ kompozit bevonatok $^{9,10}$}

A kutatómunka egyik fö célkitüzése antibakteriális tulajdonságú $\mathrm{TiO}_{2}$-bevonatok kialakítása volt, melynek során az ezüstadalékolás módjának hatását tanulmányoztuk $\mathrm{Ag} / \mathrm{TiO}_{2}$ kompozit bevonatok antibakteriális aktivitásának időtállóságára. Előállítottunk ezüstöt nem tartalmazó és ezüsttartalmú $\mathrm{TiO}_{2}$-bevonatokat. Ezüsttartalmú bevonatok kialakítására két eltérő módszert alkalmaztunk: $\mathrm{AgNO}_{3}$ vizes oldatával impregnáltuk a mezopórusos $\mathrm{TiO}_{2}$-bevonatokat, illetve $\mathrm{AgNO}_{3}$-ot adtunk felületaktív anyagot nem tartalmazó $\mathrm{TiO}_{2}$ prekurzor szolhoz. A bevonatok Escherichia coli baktériummal szemben mutatott hatását mikrobiológiai módszerekkel tanulmányoztuk. A vizsgálatokat sötétben tartott és látható fénnyel bevilágított minták esetén egyaránt elvégeztük. Vizsgáltuk az

\footnotetext{
† Albert Emőke megegyező címü PhD dolgozatához kapcsolódó Tézisfüzet alapján készült.

*Tel.: +36-1-463-1111/5772; fax: +36-1-463-3767; e-mail: emokealbert@mail.bme.hu
} 
ezüstadalék jellegének és mennyiségének, valamint a kompozit bevonat szerkezeti jellemzőinek az antibakteriális tulajdonság időtállóságára kifejtett hatását.

Antibakteriális hatás már az ezüstöt nem tartalmazó $\mathrm{TiO}_{2}$-bevonatok esetén jelentkezett, ami az adalékolás hatására további, számottevő növekedést mutatott (1. ábra). Kísérleteink során nem találtunk antibakteriális hatásnövekedést a látható fénnyel bevilágított minták esetén (vö. 1. (a) és (b) ábrákat). Ez annak tudható be, hogy az ezüsttartalom nagymértékü baktériumgátló hatása elfedi a bevonat fotokatalitikus hozzájárulását az antibakteriális tulajdonsághoz.
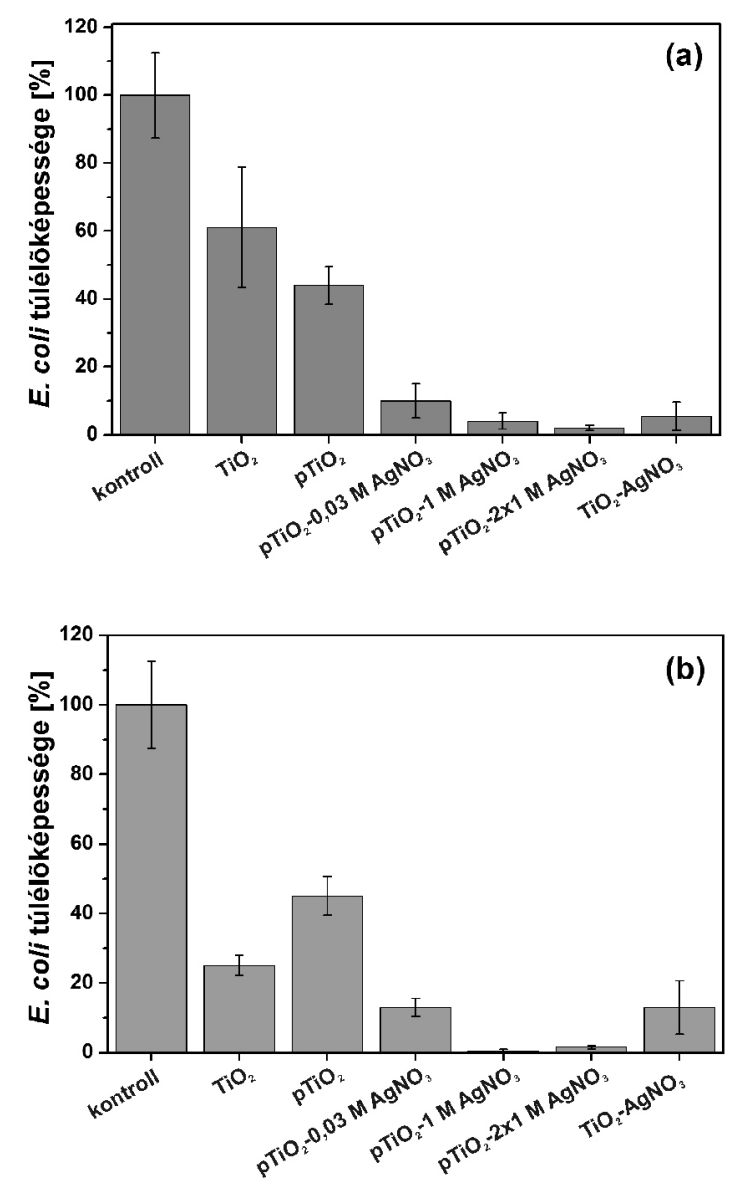

1. Ábra. E. coli baktériumok telepszámlálásos módszerrel meghatározott túlélőképessége (a) sötétben tartott és (b) látható fénnyel bevilágított kontroll üveglap, $\mathrm{TiO}_{2}$, és CTAB templát alkalmazásával kialakított $\mathrm{TiO}_{2}\left(\mathrm{pTiO}_{2}\right)$ bevonatok, illetve az utóbbi $0,03 \mathrm{M} \mathrm{AgNO}_{3}\left(\mathrm{pTiO}_{2}-0,03 \mathrm{M} \mathrm{AgNO}_{3}\right)$, $1 \mathrm{M} \mathrm{AgNO}_{3}\left(\mathrm{pTiO}_{2}-1 \mathrm{MAgNO}_{3}\right)$ és egymást követően kétszer $1 \mathrm{M} \mathrm{AgNO}_{3}$ $\left(\mathrm{pTiO}_{2}-2 \times 1 \mathrm{M} \mathrm{AgNO}_{3}\right.$ ) oldatokkal impregnált változatai, valamint az $\mathrm{AgNO}_{3}$ tartalmú prekurzor szolból készített $\left(\mathrm{TiO}_{2}-\mathrm{AgNO}_{3}\right)$ bevonatok felületén.

A bevonatok ezüsttartalmát Rutherford visszaszórási spektrometriával $(R B S)$ és elméleti úton is meghatároztuk.
1. Táblázat. $0,03 \mathrm{M} \mathrm{AgNO}_{3}\left(p \mathrm{TiO}_{2}-0,03 \mathrm{MAgNO}_{3}\right), 1 \mathrm{M} \mathrm{AgNO}_{3}$ $\left(\mathrm{pTiO}_{2}-1 \mathrm{M} \mathrm{AgNO}_{3}\right)$ és egymást követően kétszer $1 \mathrm{M} \mathrm{AgNO}_{3}$ $\left(\mathrm{pTiO}_{2}-2 \times 1 \mathrm{M} \mathrm{AgNO}_{3}\right)$ oldatokkal impregnált mezopórusos $\mathrm{TiO}_{2}$ bevonatok, valamint az $\mathrm{AgNO}_{3}$ tartalmú prekurzor szolból készített $\left(\mathrm{TiO}_{2}-\mathrm{AgNO}_{3}\right)$ bevonat elméletileg becsült és RBS módszerrel meghatározott ezüsttartalma.

\begin{tabular}{ccc}
\hline Minta jelc & $\begin{array}{c}\text { Elméletileg } \\
\text { becsült } \\
\text { ezüsttartalom } \\
\text { [at\%] }\end{array}$ & $\begin{array}{c}\text { RBS-sel } \\
\text { meghatározott } \\
\text { ezüsttartalom [at\%] }\end{array}$ \\
\hline $\mathrm{pTiO}_{2}-0,03 \mathrm{M} \mathrm{AgNO}_{3}$ & 0,007 & 0,265 \\
$\mathrm{pTiO}_{2}-1 \mathrm{M} \mathrm{AgNO}_{3}$ & 0,229 & 0,596 \\
$\mathrm{pTiO}_{2}-2 \times 1 \mathrm{M} \mathrm{AgNO}_{3}$ & 0,455 & 1,961 \\
$\mathrm{TiO}_{2}-\mathrm{AgNO}_{3}$ & 3,282 & 2,597 \\
\hline
\end{tabular}

Az 1. táblázat a frissen készített minták elméletileg becsült és $R B S$-sel meghatározott ezüsttartalmát mutatja be. A kísérletileg meghatározott ezüsttartalom megfelelö, nagyságrendi egyezésben van a vártakkal: a legalacsonyabb, illetve legmagasabb ezüsttartalommal a $\mathrm{pTiO}_{2}-0,03 \mathrm{M} \mathrm{AgNO}_{3}$ és a $\mathrm{TiO}_{2}-\mathrm{AgNO}_{3}$ típusú bevonatok rendelkeznek. A pTiO ${ }_{2}-0,03 \mathrm{M} \mathrm{AgNO}_{3}$ típusú bevonat ezüsttartalma meglepöen magasabb, mint a becsült érték, és a másik két impregnált bevonat is magasabb ezüstkoncentrációval rendelkezik, mint azok számított értékei. Ennek oka az ezüstionok adszorpciós eredetü felhalmozódása lehet a pórusrendszerben az impregnálás során.

A $p \mathrm{TiO}_{2}-\mathrm{AgNO}_{3}$ típusú bevonatok esetén az antibakteriális hatás összefüggésben volt a pórusrendszerbe impregnálással bejuttatott ezüst mennyiségével (2. (a) és (b) ábrák). Az impregnált minták ezüsttartalma, az ezüstion-leadás következtében, az első antibakteriális teszt során gyors csökkenést mutatott (2. (b) ábra). Ez arra enged következtetni, hogy az ezüst mennyisége jóval meghaladta a legkisebb gátló koncentrációt $\left(323 \mu \mathrm{g} / \mathrm{l} \mathrm{AgNO}_{3}\right.$ E.coli esetén $^{14}$ ) az első felhasználás során. A minták ezüsttartalma ezután egy közel konstans értéket vett fel, kezdeti mennyiségüktől függően. A legkisebb mennyiségű ezüstöt tartalmazó impregnált minta $\left(\mathrm{pTiO}_{2}-0,03 \mathrm{M} \mathrm{AgNO}_{3}\right)$ antibakteriális hatása azonban az első felhasználást követően megszünt, a maradék ezüsttartalom $(0,166$ at\%) a további vizsgálatok során nem mutatott aktivitást. A magasabb ezüsttartalommal rendelkező minták ( $p \mathrm{TiO}_{2}-1 \mathrm{M} \mathrm{AgNO}_{3}$ és $\mathrm{pTiO}_{2}-2 \times 1 \mathrm{M} \mathrm{AgNO}_{3}$ ) megörizték baktériumgátló hatásukat az ismételt felhasználások során, akár 20 óra elteltével is (2. (a) és (b) ábrák). Ezen előnyös tulajdonságok az ezüsttartalom pórusrendszer impregnálása révén kialakult jellegének és a pórusok méretkorlátozó sajátságának tudhatók be: az ezüsttartalom a pórusrendszerben eloszlatott formában van jelen és hozzáférhetőnek bizonyult az antibakteriális tesztek során. 
$\mathrm{Az}$ ezüstöt a tömbi $\mathrm{TiO}_{2}$ mátrixban tartalmazó bevonat $\left(\mathrm{TiO}_{2}-\mathrm{AgNO}_{3}\right)$, magasabb ezüsttartalma ellenére, nem mutatott megnövekedett antibakteriális hatást. Ezen minta ezüsttartalma nem változott 20 óra kontaktidő után sem, azonban antibakteriális hatása már az első felhasználást követően megszünt (2. (a) és (b) ábrák).
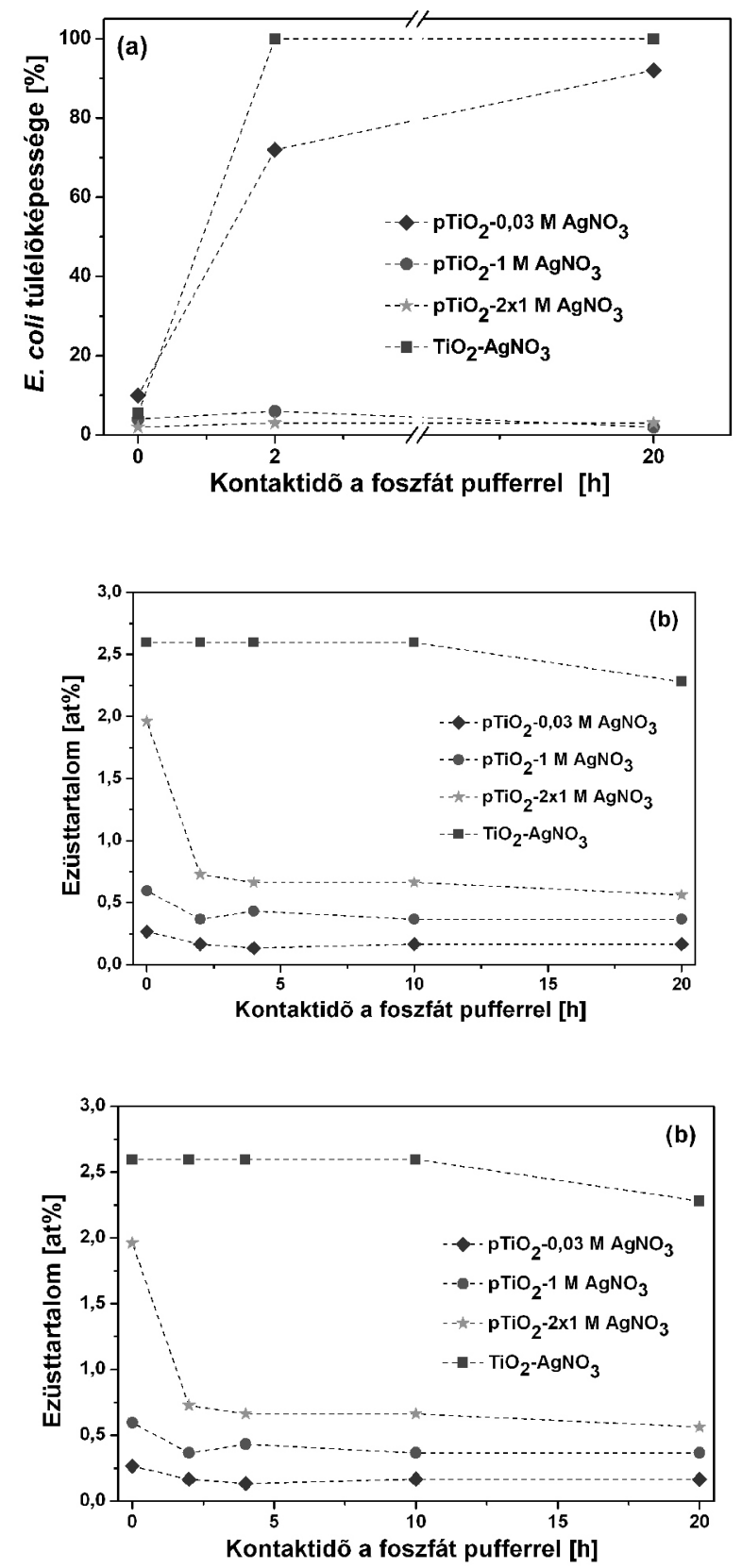

2. Ábra. (a) $E$. coli baktériumok túlélőképessége $0,03 \mathrm{M} \mathrm{AgNO}_{3}$ $\left(\mathrm{pTiO}_{2}-0,03 \mathrm{MAgNO}_{3}\right), 1 \mathrm{M} \mathrm{AgNO}_{3}\left(\mathrm{pTiO}_{2}-1 \mathrm{MAgNO}_{3}\right)$ és egymást követően kétszer $1 \mathrm{M} \mathrm{AgNO}_{3}\left(\mathrm{pTiO}_{2}-2 \times 1 \mathrm{M} \mathrm{AgNO}_{3}\right)$ oldatokkal impregnált mezopórusos $\mathrm{TiO}_{2}$-bevonatok, valamint az $\mathrm{AgNO}_{3}$ tartalmú prekurzor szolból készített $\left(\mathrm{TiO}_{2}-\mathrm{AgNO}_{3}\right)$ bevonat esetén és (b) az ugyanolyan típusú minták RBS módszerrel meghatározott ezüsttartalma a foszfát pufferel való kontaktidő függvényében.
Ennek magyarázatát az ezüsttartalom jellegében találtuk. Míg az impregnálással előállított, $\mathrm{pTiO}_{2}-1 \mathrm{M} \mathrm{AgNO}_{3}$ típusú bevonat felületén $1020 \mathrm{~nm}$ átmérőjü ezüstrészecskék láthatók (3. (a) ábra), a $\mathrm{TiO}_{2}-\mathrm{AgNO}_{3}$ típusú bevonat felületén számos kristályos ezüstrészecske található. Ez utóbbi esetben a részecskék jellemző átmérője $100 \mathrm{~nm}$ feletti volt, de néhány $50 \mathrm{~nm}$ körüli, kisebb részecske is előfordult (3. (b) ábra).

Az irodalom alapján az ezüst nanorészecskék Escherichia coli elleni hatásukat $5060 \mathrm{~nm}$ alatti átmérő esetén fejtik ki. Ez alapján a $\mathrm{TiO}_{2}-\mathrm{AgNO}_{3}$ típusú minta baktériumgátló hatása ezeknek, a bevonatok felületén kis mennyiségben előforduló részecskéknek tudható be. A részecskék az első felhasználás során valószínüleg elhagyják a minta felületét, aminek következtében az ismételt tesztek során nem tapasztalható antibakteriális hatás. Bár a bevonat anyagában jelenlévő ezüstrészecskék dimenziója az 5060 nm határértéknél kisebb, ezek a baktérium számára nem hozzáférhetőek. Ezen feltevést az agardiffúziós vizsgálatok is alátámasztották, melyek azt mutatták, hogy a bevonatok ezüstion-leadása egyértelmüen gátolt és ezen minták elsősorban közvetlen kontaktus révén fejtik ki baktériumgátló hatásukat.
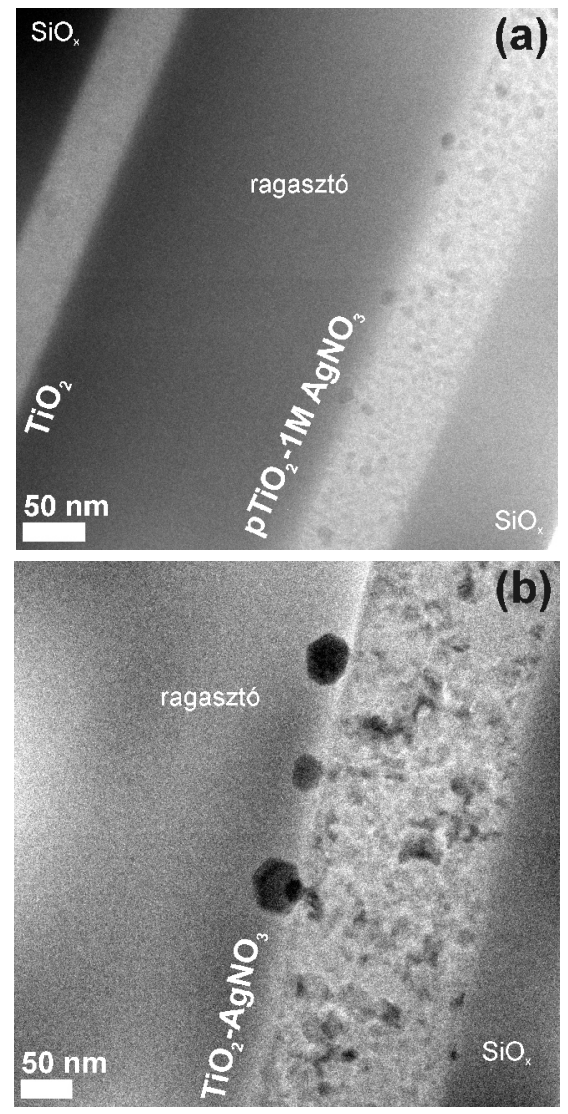

3. Ábra. (a) $\mathrm{TiO}_{2}$ (bal) és $1 \mathrm{M} \mathrm{AgNO}_{3}$ oldattal impregnált pórusos $\mathrm{TiO}_{2}$ (jobb, pTiO $\mathrm{TH}_{2}-1 \mathrm{MgNO}_{3}$ ), valamint (b) $\mathrm{AgNO}_{3}$ tartalmú prekurzor szolból készített $\left(\mathrm{TiO}_{2}-\mathrm{AgNO}_{3}\right)$ bevonatok keresztmetszeti elektron energiaveszteségi spektroszkópiával nyert képei. 


\subsection{Korróziógátló kompakt és pórusos $\mathrm{SiO}_{2}$ - bevonatok $^{9,11,12}$}

A kutatómunka másik témája különböző típusú, korróziógátló $\mathrm{SiO}_{2}$-bevonatok elöállítása és tulajdonságainak vizsgálata volt, hangsúlyt helyezve az elöállítási paraméterek a bevonatok permeabilitására gyakorolt hatásának tanulmányozására. Szubmikrométeres vastagságú, kompakt és mezopórusos $\mathrm{SiO}_{2}$ szol-gél bevonatokat hoztunk létre $\mathrm{Zn}$-felületeken (bizonyos vizsgálatokhoz üveg- és Si-hordozókon). A mezopórusos bevonatok kialakítására Pluronic és CTAB típusú felületaktív anyagokat használtunk. A korróziógátló hatás növelésére a bevonatok felületét monofunkciós (trimetil-klórszilán, TMClSi), vagy bifunkciós (dimetildiklórszilán, $D M D C l S i$ ) szililezőszerekkel hidrofobizáltuk. A vékonyrétegek permeabilitását, korróziógátló hatását a rétegvastagság, hidrofobitás és mezopórusos struktúra szempontjából tanulmányoztuk.

Mindegyik vizsgált minta korróziós tulajdonsága számottevően jobbnak bizonyult a bevonat nélküli cinkhordozóénál, a korróziós áramsürűség-értékek egy, kettő, vagy akár három nagyságrenddel csökkentek a cinklemez esetén mért $\left(12,15 \pm 0,912 \mu \mathrm{A} / \mathrm{cm}^{2}\right)$ értékekhez képest. Az ellenállóképesség a vártnak megfelelően alakult, a vizsgált tartományban $(130-350 \mathrm{~nm})$ a bevonatok vastagságával arányosnak adódott (4. ábra).

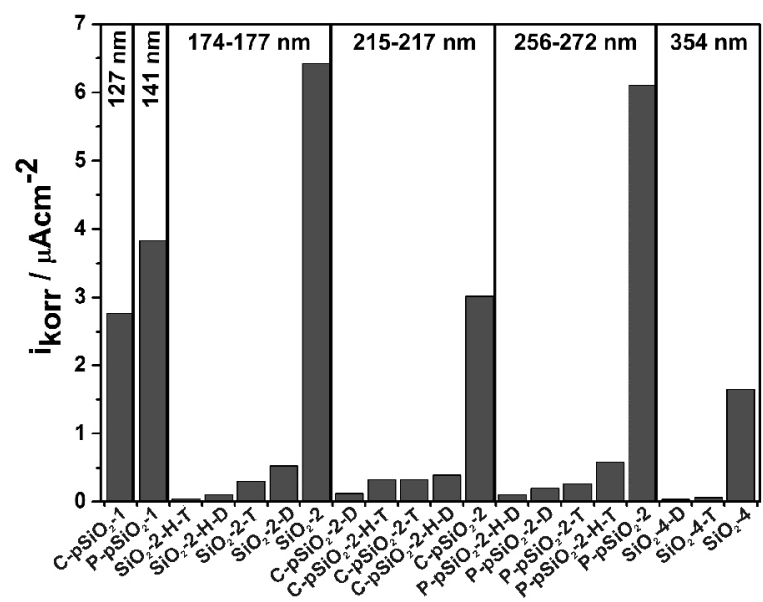

4. Ábra. Polarizációs görbék elemzésével nyert korróziós áramsűrüségértékek összefoglalója rétegvastagság szerinti csoportosításban (p: pórusos; C: cetil-trimetil-ammónium-bromid; P: Pluronic PE 10300; 1, 2, 4: rétegszám; $\mathrm{H}$ : mindegyik rétegképzés után hőkezelt;

D: dimetil-diklórszilán; T: trimetil-klórszilán).

A pórusos bevonatok permeabilitása, illetve védőhatása megközelítőleg azonos volt a kompakt rétegekével, ami a felületaktív anyagot tartalmazó prekurzor szolok jobb rétegképző tulajdonságával, valamint azzal magyarázható, hogy a pórusok a hordozó oldalán nem nyitottak. A nem hidrofobizált, kétrétegủ pórusos bevonatok közül valamivel jobb korróziógátló hatást tapasztaltunk a $C T A B$-val kialakított pórusrendszerủ mintáknál (4. ábra). Ennek hátterében a kétrétegű pórusos bevonatok különböző pórusszerkezete és folyadékfelvevő képessége áll.
A szorpciós izotermák jellege és a nagyfelbontású transzmissziós elektronmikroszkópos (HRTEM) felvételek (5. ábra) alapján megállapítható, hogy CTAB templát alkalmazásával részlegesen rendezett, a felülettel párhuzamosan orientálódott, hengeres pórusok, míg Pluronic templát alkalmazásakor rendezetlen szerkezetủ, szabálytalan alakú pórusok képződtek. Megjegyzendő, hogy a Rodamin 6G színezékkel, mint modellinhibitorral végzett kísérletek során csupán a Pluronic típusú bevonatok pórusrendszere bizonyult hozzáférhetőnek a színezékmolekulák számára.

A minták felületének bármelyik szililezőszerrel végzett hidrofobizálása révén a korróziós áramsürüség-értékek további egy, vagy két nagyságrenddel csökkentek, mind a kompakt, mind a pórusos bevonatok esetén (4. ábra). Elmondható tehát, hogy a szililezés előnyös hatása kettős: amellett, hogy javítja a korrózióval szembeni ellenállóképességet, képes megvédeni a pórusrendszer vízoldható inhibitortartalmát a pórusokból való gyors kioldódás ellen, mint ahogy azt a színezékleadás vizsgálati eredményei mutatják (6. ábra). Ezáltal az így létrehozott rétegszerkezetek lehetőséget nyújtanak öngyógyító korróziógátló bevonatok kialakítására.
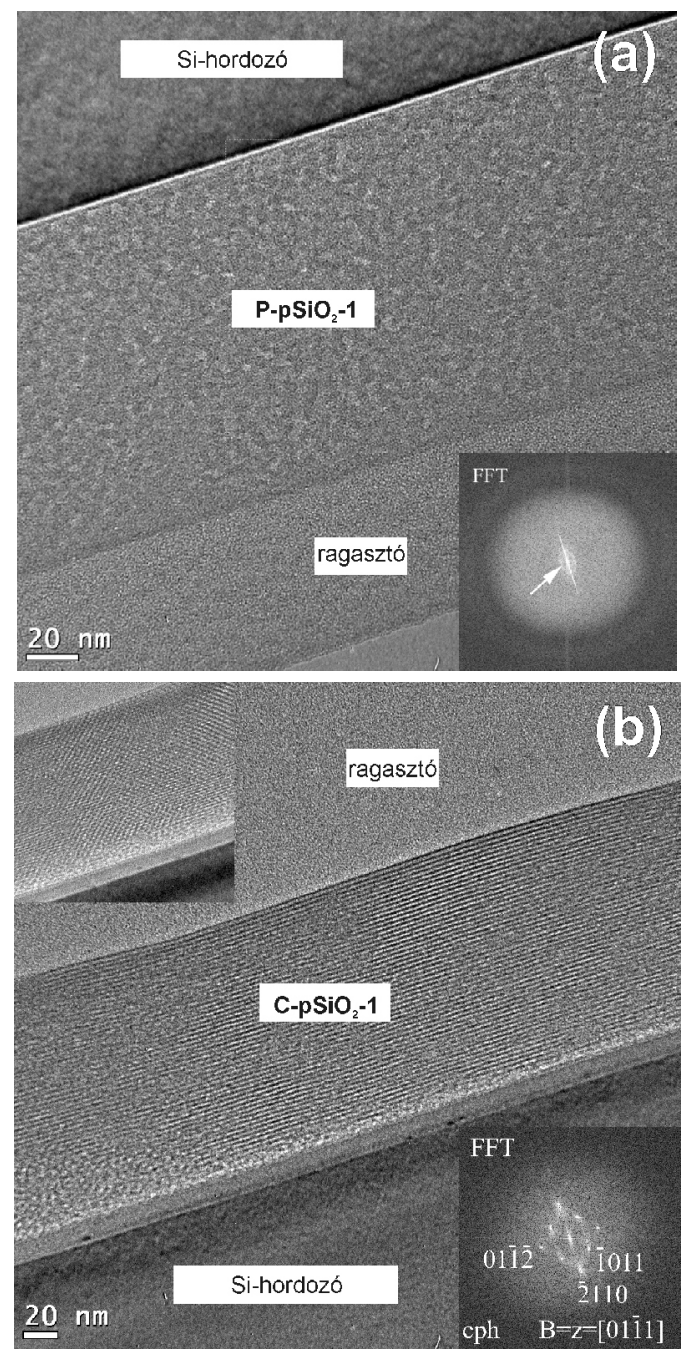

5. Ábra. Egyrétegű (a) Pluronic típusú $\left(P-p S i O_{2}-1\right)$ és (b) CTAB típusú $\left(\mathrm{C}-\mathrm{pSiO} \mathrm{O}_{2}-1\right)$ pórusos $\mathrm{SiO}_{2}$-bevonatok keresztmetszeti HRTEM képei. 


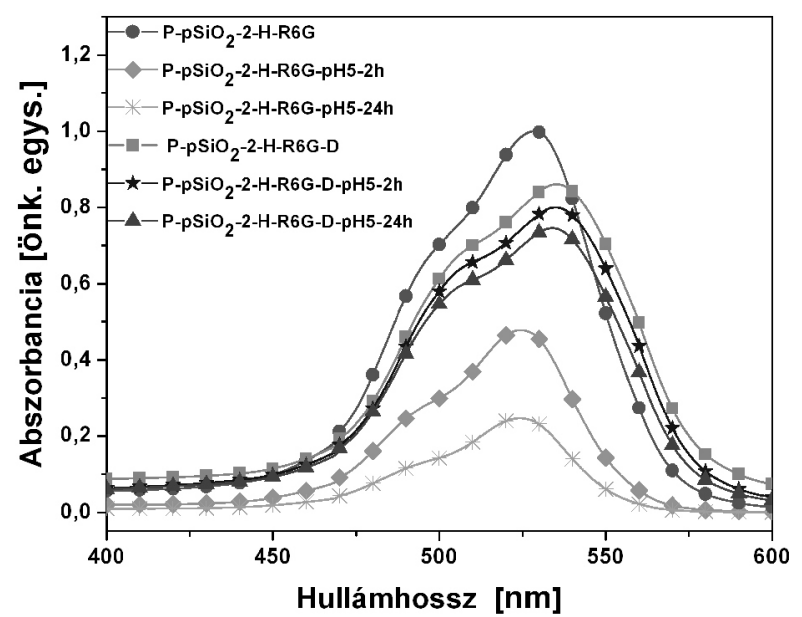

6. Ábra. Rodamin 6G (R6G) színezéket tartalmazó, kétrétegü (2), Pluronic (P) típusú pórusos (p) $\mathrm{SiO}_{2}$-bevonatok abszorbancia spektrumai: a frissen impregnált bevonatok, az impregnálás után szililezett (D) bevonatok és ezek nátrium-szulfát oldatban $(\mathrm{pH}=5,0) 2$ órás és 24 órás áztatás után. A bevonatokat mindkét réteg kialakítása után hökezeltük $(\mathrm{H})$.

\subsection{Nanostrukturált felületü mezopórusos $\mathrm{SiO}_{2}$ - bevonatok $^{9,13}$}

A munka harmadik fő célkitűzése a mezopórusos jelleg és a szubmikrométeres léptékü felületi morfológia előnyös tulajdonságait egyesítő, speciális szol-gél bevonatok kialakítása volt. Rendezetlen és rendezett pórusrendszerü mezopórusos $\mathrm{SiO}_{2}$-bevonatokat alakítottunk ki Pluronic és $C T A B$ templátokkal. A pórusos bevonatok felületére $\mathrm{SiO}_{2}$ nanorészecskék hexagonális elrendeződésü LangmuirBlodgett-típusú filmjeit képeztük, melyeket maszkként használtuk a morfológia kialakítására alkalmazott $\mathrm{Xe}^{+}$ ionbesugárzással szemben. A felületi morfológia az ionbombázás tömörítő hatására alakult ki, azaz az ionok tömörítették a szol-gél bevonatot ott, ahol a részecskékből felépülő maszk nyílásain keresztül elérték a mezopórusos bevonat felületét (7. ábra).

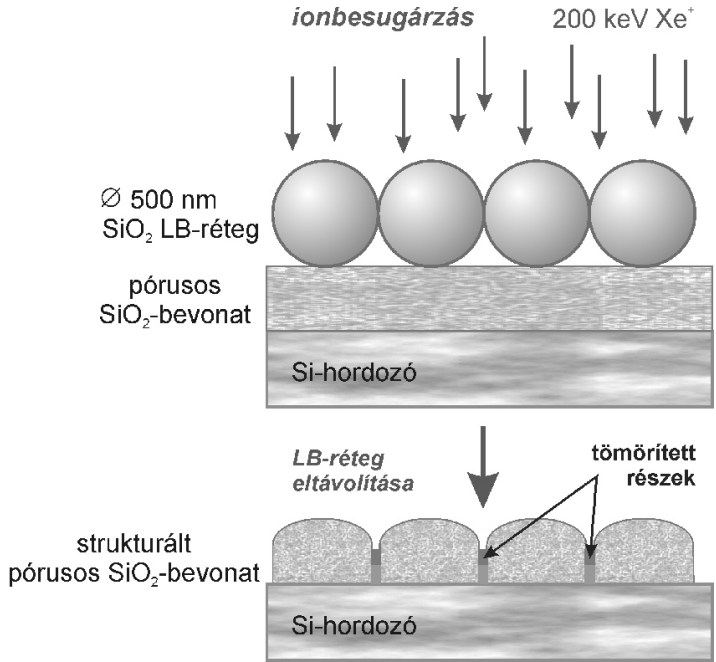

7. Ábra. A mintakészítés sematikus ábrája: $200 \mathrm{keV} \mathrm{Xe}{ }^{+}$ionbesugárzás rendezett, nanoméretű $\mathrm{SiO}_{2}$-részecskék monorétegén keresztül, majd a részecskékből felépülő maszk mechanikai eltávolítása.
A keletkezett morfológia méretarányai nagynak mutatkoztak, a kialakított felületi struktúrák az alkalmazott templáttól és ionbombázás dózisától függetlenül nagyon hasonlóak voltak (8. ábra). Mindkét típusú pórusos $\mathrm{SiO}_{2}$-bevonat már a legalacsonyabb dózis mellett elérte tömörödésének közel maximumát. A tömörödés mértéke a $C T A B$ típusú bevonatok esetén számottevően nagyobb volt, mint a Pluronic típusúaknál (9. Ábra).
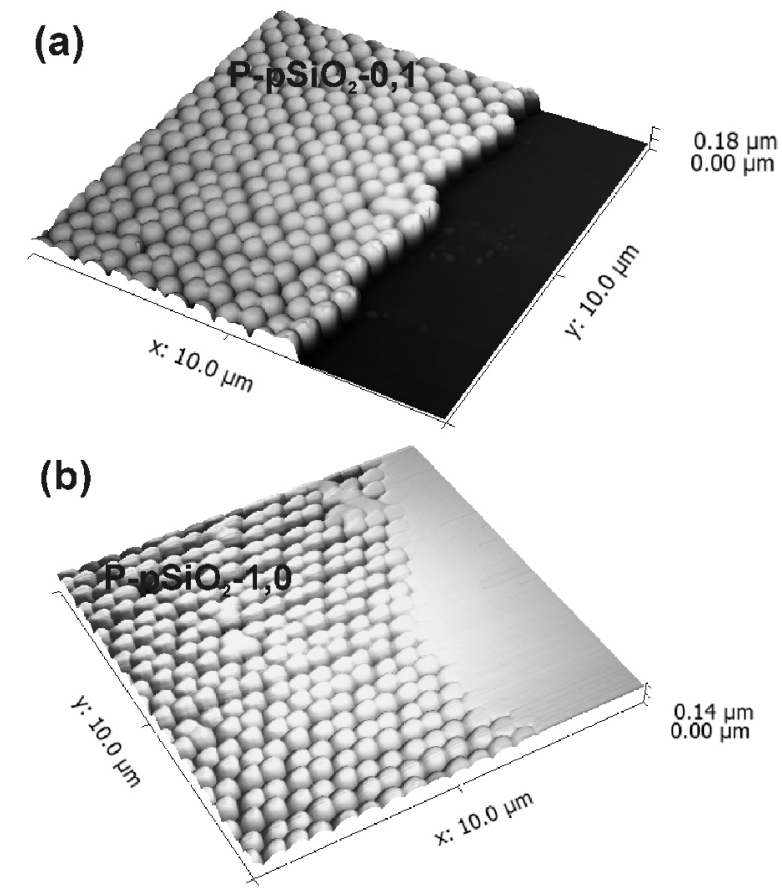

8. Ábra. Pluronic típusú $\mathrm{SiO}_{2}$-bevonat felületi morfológiájának atomerő mikroszkóppal mért 3D-s megjelenítése (a) $0,1 \times 10^{16} \mathrm{~cm}^{-2}\left(P-p S i O_{2}-0,1\right)$ és (b) $1 \times 10^{16} \mathrm{~cm}^{-2}\left(P-p S i O_{2}-1,0\right)$ dózisú ionbesugárzás és a részecskékből felépülő maszk eltávolítása után. A méréseket (a) a nanoméretű részecskékből felépülő LB-maszk peremének helyén és (b) az LB-maszk besugárzott és nem besugárzott régióinak határán végeztük (a jobb oldalon egy további fémlap is maszkként szolgált).

A HRTEM vizsgálatok kimutatták, hogy azokon a helyeken, ahol a részecskékből felépülő maszk nem transzparens a bombázó ionokkal szemben, a pórusszerkezet sértetlen maradt (9. ábra). A Pluronic típusú, rendezetlen pórusrendszerrel rendelkező bevonatok esetén a legkisebb dózis alkalmazásakor a pórusszerkezet átjárható maradt a szilíciumhordozó felülete mentén (9. (a) ábra). Ezzel szemben, a legnagyobb dózis alkalmazása esetén a sértetlen pórusos oszlopokat övező régiók teljes mértékben tömörödtek, ily módon kompakt határoló tartományokat képezve (9. (a) ábra). A pórusrendszer átjárható, vagy elkülönített jellege tehát az ionbesugárzás dózisával szabályozható, alapvetően azonos felületi morfológia kialakítása mellett. A rendezett pórusszerkezettel rendelkező $C T A B$ típusú bevonatok esetén nyert eredmények ehhez hasonlóak (9. (b) ábra). A tömörített régiók vastagabbak, míg a sértetlen pórusos tartományok vékonyabbak, mint az ugyanolyan dózissal besugárzott Pluronic típusú mintáknál. A két különböző molekuláris templátot összehasonlítva, a Pluronic típusú, rendezetlen pórusszerkezet sokkal ellenállóbbnak bizonyult a $\mathrm{Xe}^{+}$ionbesugárzással szemben, mint a CTAB típusú, rendezett pórusszerkezet (9. (A) és (b) ábrák). 

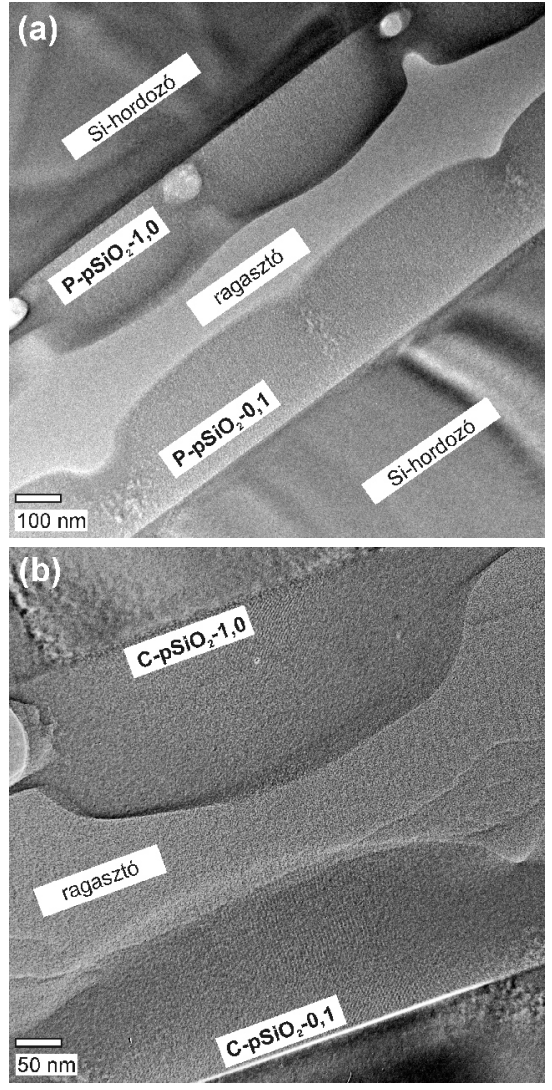

9. Ábra. $0,1 \times 10^{16} \mathrm{~cm}^{-2}\left(P-p S i O_{2}-0,1 ; C-p S i O_{2}-0,1\right)$ és $1,0 \times 10^{16} \mathrm{~cm}^{-2}$ $\left(P-p \mathrm{SiO}_{2}-1,0 ; \mathrm{C}-\mathrm{pSiO} \mathrm{2}_{-}^{-1,0)}\right.$ dózisú $\mathrm{Xe}^{+}$ionokkal besugárzott (a) Pluronic típusú $\left(P-p \mathrm{SiO}_{2}-0,1\right.$ és $\left.P-p \mathrm{SiO}_{2}-1,0\right)$, illetve (b) CTAB típusú

$\left(\mathrm{C}-\mathrm{p} \mathrm{SiO}_{2}-\mathrm{O}, 1\right.$ és $\left.\mathrm{C}-\mathrm{p} \mathrm{SiO}_{2}-1,0\right)$ bevonatok HRTEM képei. A besugárzás nanoméretű $\mathrm{SiO}_{2}$ részecskékből felépülő maszkon keresztül történt.

A strukturált pórusszerkezet átjárhatóságának vizsgálata céljából a strukturált mezopórusos bevonatokat Rodamin 6G színezék vizes oldatával impregnáltuk, majd konfokális fluoreszcens vizsgálatokkal minősítettük azokat. A legnagyobb dózissal besugárzott Pluronic típusú, és a legkisebb dózissal kezelt $C T A B$ típusú minták a hasonló mértékü tömörödés következtében hasonló kontrasztot és intenzitást mutattak, ami jó egyezésben van a HRTEM eredményekkel (10. ábra).
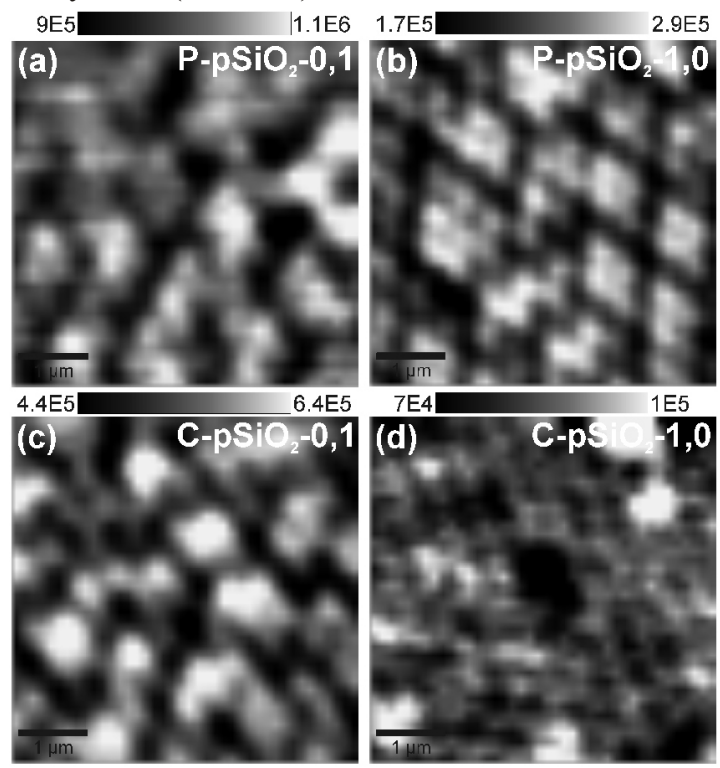

10. Ábra. (a, c) $0,1 \times 10^{16} \mathrm{~cm}^{-2}$ és (b, d) $1 \times 10^{16} \mathrm{~cm}^{-2}$ dózisú Xe $\mathrm{Xe}^{+}$ ionbesugárzással kialakított, $10^{-4} \mathrm{M}$ R6G oldattal impregnált (a, b) Pluronic és (c, d) CTAB típusú nanostrukturált $\mathrm{SiO}_{2}$-bevonatok konfokális fluoreszcens képei. A felső skála a CCD beütésszámokat mutatja.

2. Táblázat. $0,1 \times 10^{16} \mathrm{~cm}^{-2}\left(P-p S i O_{2}-0,1\right.$ és $\left.C-p S i O_{2}-0,1\right)$ és $1 \times 10^{16} \mathrm{~cm}^{-2}$ $\left(P-p \mathrm{SiO}_{2}-1,0\right.$ és $C$ - $\left.p \mathrm{SiO}_{2}-1,0\right)$ dózisú $\mathrm{Xe}^{+}$ionbesugárzással strukturált Pluronic és CTAB típusú bevonatok ellipszometriai porozimetriával meghatározott porozitásértékei.

\begin{tabular}{cc}
\hline Minta jele & Porozitás \\
\hline $\mathrm{P}_{\mathrm{pSiO}}-0,1$ & 37,9 \\
$\mathrm{P}-\mathrm{pSiO}_{2}-1,0$ & 14,2 \\
$\mathrm{C}-\mathrm{pSiO}_{2}-0,1$ & 20,5 \\
$\mathrm{C}-\mathrm{pSiO}_{2}-1,0$ & 7,9 \\
\hline
\end{tabular}

A nanostrukturált pórusos szilikabevonatokat ellipszometriai porozimetriával minősítettük, az ionbesugárzás után hozzáférhető pórusok arányának számszerüsítése és a pórusrendszer jellemzése céljából. Az eredmények megerősítették, hogy a sértetlen tartományokban a pórusrendszer érintetlenül megmaradt, míg a besugárzott részeken teljes mértékben tömörödött. A legkisebb alkalmazott dózis esetén az átmeneti zónák hozzájárulása a porozitáshoz hiányzik, vagy elhanyagolható. A porozitásváltozás tendenciája az elvárásoknak megfelelően alakult: a mért porozitásértékek (2. táblázat) alátámasztották, hogy a legalacsonyabb dózis esetén a pórustérfogat nagy része összefüggő, hozzáférhető pórusrendszerként megőrizhető a felületi mintázat létrehozása mellett. Magasabb dózisok alkalmazása esetén pedig egymástól elkülönített, pórusos tartományok alakíthatók ki a teljes pórustérfogat rovására.

\section{3. Összefoglalás}

A doktori munka eredményeinek tézisszerüen megfogalmazott összefoglalója:

Különböző módon előállított, ezüsttartalmú $\mathrm{TiO}_{2}$-bevonatok antibakteriális hatását tanulmányoztuk és hasonlítottuk össze. Megállapítottuk, hogy a bevonatok jelentős antibakteriális hatása kizárólag a bevonatból kilépő ezüst mennyiségének függvénye. A bevonatok fotoaktivitásának szerepe az antibakteriális hatás szempontjából elhanyagolható, ezért a bevonatok világosban és sötétben egyaránt hatásosak.

A különböző módon előállított $\mathrm{TiO}_{2}$-bevonatok ezüsttartalmát Rutherford visszaszórási spektrometriával jellemeztük. Megmutattuk, hogy a mezopórusos bevonatok impregnálásával megfelelö mennyiségű ezüst juttatható a pórusok belsejébe az antibakteriális hatás biztosításához. Kimutattuk, hogy az ezüst az impregnáló oldat töménységét jelentősen meghaladó mértékben felhalmozódik a pórusokban, ami magyarázatot ad a bevonatok Escherichia coli baktériumokkal szemben mutatott tartós antibakteriális hatására. ${ }^{9,10}$

Mezopórusos $\mathrm{SiO}_{2}$ szol-gél bevonatok permeabilitását elektrokémiai módszerekkel tanulmányoztuk. Megállapítottuk, hogy a polírozott cinkfelületeken kialakított bevonatok 
szigetelő hatása eléri a tömör (nem mezopórusos) szilika bevonatokét, mely számottevő korróziót gátló hatásban is megmutatkozik. A jelentős korrózióvédő hatás a pórusos bevonatok prekurzor szoljainak jobb filmképző tulajdonságával magyarázható.

Új eljárást dolgoztunk ki vízoldható korróziós inhibitoranyagok mezopórusos $\mathrm{SiO}_{2}$ szol-gél bevonatokban való tárolására. Az így elóállított bevonatokból vizes közegben csak a bevonatok sérülése esetén áramolhat ki a hatóanyag, mely öngyógyító hatást eredményezhet.

Kísérletileg megmutattuk, hogy az eljárás részeként alkalmazott felületi hidrofobizálás két szempontból is előnyös: javítja a korrózióval szembeni ellenállóképességet és megvédi a pórusrendszer vízoldható inhibitortartalmát a korrozív közegbe való kioldódással szemben a sértetlen bevonatból. ${ }^{9,11,12}$

Új eljárást dolgoztunk ki mezopórusos $\mathrm{SiO}_{2}$ szol-gél bevonatok felületének periodikus strukturálására a mikrométer alatti mérettartományban. $500 \mathrm{~nm}$ átmérőjü szilikarészecskék egyrétegü rendezett Langmuir-Blodgetttípusú filmjét használtuk maszkként $200 \mathrm{keV}$ energiájú Xe $\mathrm{Xe}^{+}$ ionbesugárzás során. A felületi morfológia annak eredményeként alakult ki, hogy az ionok tömörítették a mezopórusos szol-gél bevonatot ott, ahol a részecskékből felépülő maszk nyílásain keresztül elérték a bevonat felületét.

Megmutattuk, hogy a Pluronic PE 10300 molekuláris templáttal készült pórusos $\mathrm{SiO}_{2}$-rétegek rendezetlen pórusszerkezete jóval ellenállóbb a $200 \mathrm{keV}$ energiájú $\mathrm{Xe}^{+}$ ionbesugárzással szemben, mint a cetil-trimetilammónium-bromid templát alkalmazásával kialakuló rendezett pórusszerkezet.

Kísérletileg bizonyítottuk, hogy mezopórusos $\mathrm{SiO}_{2}$ bevonatok szabályozott felületi morfológiája kialakítható a $\mathrm{Xe}^{+}$ionbesugárzás dózisának megfelelő megválasztásával a pórusrendszer átjárhatóságát megőrizve, vagy kompakt régiók által elkülönített mezopórusos tartományok kialakítása mellett. ${ }^{9,13}$

\section{Kísérleti rész}

\subsection{Bevonatok előállítása}

A szilárd hordozós $\mathrm{TiO}_{2}$ és $\mathrm{SiO}_{2}$ szol-gél bevonatok előállításához különböző prekurzor szolokat szintetizáltunk. A prekurzor szolok szintézise Ti- vagy Si-alkoxid prekurzor anyagok alkoholos közegü, kontrollált, savkatalizált hidrolízisén és polikondenzációján alapult. Mindkét esetben létrehoztunk felületaktív anyagot nem tartalmazó, illetve felületaktív anyag (Pluronic PE 10300, cetil-trimetilammónium-bromid) tartalmú prekurzor szolokat. A felületaktív anyag tartalmú prekurzor szolokat pórusos vékonyrétegek kialakítására használtuk. A félvezető $\mathrm{TiO}_{2}$ esetén ezüsttartalmú prekurzor szolt is elöállítottunk.

A szol-gél bevonatokat mártásos (dip-coating) technikával alakítottuk ki üveg-, cink- és szilíciumhordozók felületén. Rétegképzés után a mintákat magas hőmérsékletü $\left(410{ }^{\circ} \mathrm{C}\right.$, illetve $450^{\circ} \mathrm{C}$ ) kezeléssel kondicionáltuk.

\subsection{Bevonatok utókezelése}

A $\mathrm{TiO}_{2}$-bevonatok esetén az ezüsttartalmú prekurzor szol alkalmazása mellett $\mathrm{AgNO}_{3}$-tal impregnált pórusos vékonyrétegeket is kialakítottunk. Az impregnálást a réteghúzó berendezéssel végeztük $0,03 \mathrm{M}$ és $1,0 \mathrm{M}$ koncentrációjú vizes közegü $\mathrm{AgNO}_{3}$-oldatokat alkalmazva. $\mathrm{Az} \mathrm{Ag}^{+}$ionok fémezüstté történő redukálása céljából az ezüsttel impregnált mintákat hőkezeltük.

A $\mathrm{SiO}_{2}$-bevonatok egy részét kémiai felületmódosítással hidrofobizáltuk. Erre a célra dimetil-diklórszilán, illetve trimetil-klórszilán $1 \mathrm{~V} / \mathrm{V} \%$-os hexános oldatait használtuk. A mintákat 1 órán át tartottuk a szililezőszer oldatában, majd $150{ }^{\circ} \mathrm{C}$-on szárítószekrényben kondicionáltuk azokat.

Annak érdekében, hogy információt nyerjünk a különböző típusú mezopórusos $\mathrm{SiO}_{2}$-bevonatok pórusainak hozzáférhetőségéről, modellvizsgálatokat végeztünk: Rodamin 6G színezék $10^{-3} \mathrm{M}$-os vizes oldatával impregnáltuk az üveghordozón kialakított, különböző típusú és vastagságú pórusos $\mathrm{SiO}_{2}$-bevonatokat. Az impregnálásra a réteghúzó készüléket használtuk. Megvizsgáltuk, védelmet jelent-e a felület hidrofobizálása a vízoldható korróziós inhibitor korrozív közegbe oldódása ellen. Erre a célra színezékleadási vizsgálatokat végeztünk a színezékkel impregnált és az impregnálás után hidrofobizált minták esetén $\mathrm{pH}=6,5$; $\mathrm{pH}=5,0$ és $\mathrm{pH}=2,0$ vizes oldatokat használva.

Nanostrukturált felületi morfológiájú pórusos $\mathrm{SiO}_{2}$-bevonatok kialakítása céljából az $500 \mathrm{~nm}$ átméröjü $\mathrm{SiO}_{2}$-részecskékkel maszkolt, különböző típusú pórusos bevonatokat $200 \mathrm{keV-os} \mathrm{Xe}^{+}$ionokkal sugároztuk be $0,1 \times 10^{16} \mathrm{~cm}^{-2}, 0,5 \times 10^{16} \mathrm{~cm}^{-2}$ és $1 \times 10^{16} \mathrm{~cm}^{-2}$ dózisokban.

A strukturált pórusrendszer átjárhatóságának vizsgálatára a különböző pórusrendszerü és felületi morfológiával rendelkező $\mathrm{SiO}_{2}$-bevonatokat - a nanoméretü részecskékből képzett maszk eltávolítása után - Rodamin 6G színezék $10^{-4} \mathrm{M}$-os vizes oldatával impregnáltuk.

\section{Köszönetnyilvánítás}

A szerzők köszönetet mondanak Dr. Pierre-Antoine Albouynak, Dr. André Ayralnak, Dr. Basa Péternek, Dr. Nicoleta Cotolannak, Dr. Csík Gabriellának, Dr. Deák Andrásnak, Dr. Liana-Maria Mureşannak, Dr. Nagy Norbertnek, Dr. Németh Attilának, Dr. Osváth Zoltánnak, Dr. Sáfrán Györgynek, Dr. Suhajda Ágnesnek, Dr. Szabó Gabriellának és Dr. Zolnai Zsoltnak a kutatómunkához nyújtott segítségükért, támogatásukért.

A kutatómunka anyagi támogatásáért köszönet illeti az alábbi szervezeteket és pályázatokat: BME VBK Pungor Ernő doktorjelölti pályázata, Országos Tudományos Kutatási Alapprogram (OTKA CK 78629), Nemzeti Fejlesztési Ügynökség (magyar-francia bilaterális TÉT pályázat, PHONOSEL, TéT_11-2-2012-0008 és magyar-román bilaterális TÉT pályázat, TÉT_12 RO-1-2013-0011). Albert Emőke publikációt megalapozó kutatása a TÁMOP-4.2.4.A/211/1-2012-0001 Nemzeti Kiválóság Program címü kiemelt projekt keretében zajlott. A projekt az Európai Unió támogatásával, az Európai Szociális Alap társfinanszírozásával valósul meg. A kutatómunka a "BME $\mathrm{K}+\mathrm{F}+\mathrm{I}$ stratégia" projektjének keretében készült, megvalósítását a TÁMOP 4.2.1/B-09/1/KMR-2010-0002 program támogatta. 


\section{Hivatkozások}

1. Metroke, T. L.; Parkhill, R. L.; Knobbe, E. T. Prog. Org. Coat. 2001, 41, 233-238. https://doi.org/10.1016/S0300-9440(01)00134-5

2. Wang, D.; Bierwagen, G. P. Prog. Org. Coat. 2009, 64, 327-338. https://doi.org/10.1016/j.porgcoat.2008.08.010

3. Fedel, M.; Druart, M. E.; Olivier, M.; Poelman, M.; Deflorian, F.; Rossi, S. Prog. Org. Coat. 2010, 69,118-125. https://doi.org/10.1016/j.porgcoat.2010.04.003

4. Li, M.; Noriega-Trevino, M. E.; Nino-Martinez, N.; Marambio-Jones, C.; Wang, J.; Damoiseaux, R.; Ruiz, F.; Hoek, E. M. V. Environ. Sci. Technol. 2011, 45, 8989-8995. https://doi.org/10.1021/es201675m

5. Hendry, A. T.; Stewart, I. O. Can. J. Microbiol. 1979, 25, 915-921. https://doi.org/10.1139/m79-136

6. Ciriminna, R.; Fidalgo, A.; Pandarus, V.; Béland, F.; Ilharco, L. M.; Pagliaro, M. Chem. Rev. 2013, 113, 65926620

7. Liu, Y.; Wang, X.; Yang, F.; Yang, X. Micropor. Mesopor. Mat. 2008,114, 431-439.

https://doi.org/10.1016/j.micromeso.2008.01.032
8. Dabóczi, M.; Albert, E.; Agócs, E.; KabaiFaix, M.; Hórvölgyi, Z. Carbohyd. Polym. 2016, 136, 137145.

9. Albert, E. Mezopórusos szol-gél bevonatok: elöállitás, jellemzés, alkalmazás, PhD értekezés, Budapesti Műszaki és Gazdaságtudományi Egyetem, 2015.

10. Albert, E.; Albouy, P. A.; Ayral, A.; Basa, P.; Csík, G.; Nagy, N.; Roualdčs, S.; Rouessac, V.; Sáfrán, Gy.; Suhajda, Á.; Zolnai, Zs.; Hórvölgyi, Z. RSC Adv. 2015, 5, 5907059081.

11. Albert, E.; Cotolan, N.; Nagy, N.; Sáfrán, Gy.; Szabó, G.; Mureşan, L. M.; Hórvölgyi, Z.

Micropor. Mesopor. Mat.2015, 206, 102113.

12. Volentiru, E.; Nyári, M.; Szabó, G.; Hórvölgyi, Z.; Mureșan, L. M. Period. Polytech. Chem. 2014, 58, 6166.

13. Albert, E.; Basa, P.; Deák, A.; Németh, A.; Osváth, Z.; Sáfrán, Gy.; Zolnai, Zs.; Hórvölgyi, Z.; Nagy, N. RSC Adv. 2015, 5, 6004160053 .

14. Lok, C.; Ho, C.; Chen, R.; He, Q.; Yu, W.; Sun, H.; Tam, P. K.; Chiu, J.; Che, C. J. Biol. Inorg. Chem. 2007, 12, 527-534. https://doi.org/10.1007/s00775-007-0208-z

\section{Mesoporous sol-gel coatings: preparation, characterization, application ${ }^{\star}$}

The importance of materials with designed surface properties has recently increased. It can be achieved by applying functional coatings on the surfaces. Novel advantageous surface properties can be obtained by utilizing nanostructured coatings - preserving the beneficial character of the substrate material. Special coatings are intensively researched with designed optical, electrical, and mechanical properties, as well as with photocatalytic, photovoltaic, non-sticky, anti-corrosion, ${ }^{1,2}$ water repellent, ${ }^{3}$ antibacterial, ${ }^{4,5}$ self-cleaning behaviour. The sol-gel process has the advantage that the structure, morphology, and physicochemical properties of the coatings can be tuned in wide range by varying the experimental parameters. ${ }^{6}$ The pore system of mesoporous thin films can be utilized for delivery of different nanoparticles, corrosion inhibitors, and drug molecules. ${ }^{7,8}$

The main aim of the work was the preparation and investigation of mesoporous and (in some cases for comparison) compact sol-gel coatings with antibacterial and anti-corrosion properties. Furthermore, we aimed the development of a novel method for combining the advantageous properties of mesoporous character and periodic surface morphology. Mesoporous coatings were prepared by using two different (Pluronic PE 10300 and cetyltrimethylammonium bromide) surfactants. Coatings with thicknesses of some hundred nanometers were deposited onto different solid substrates by the dip-coating sol-gel technique. ${ }^{9}$

Surfaces with antibacterial properties were prepared from silver containing $\mathrm{TiO}_{2}$ coatings on glass substrates. The effect of the coating's structure, silver-doping method, size and amount of the resulted silver nanoparticles on the long-lasting antibacterial behaviour was studied. We demonstrated that the antibacterial effect of the coatings only depends on the amount of released silver. The role of photoactivity of the coatings is negligible, hence the coatings are active both in the dark and under illumination (Figure 1). The silver content of the $\mathrm{TiO}_{2}$ coatings prepared by different methods was determined by Rutherford backscattering spectrometry (Table 1). It was shown that appropriate amount of silver can be impregnated into the pore system of the mesoporous coatings to ensure the antibacterial behaviour of the coatings. We confirmed that the silver content accumulates in the pores above the concentration of the impregnating solution resulting in the long-lasting antibacterial behaviour of the coatings against Escherichia coli. ${ }^{9,10}$

Anti-corrosion $\mathrm{SiO}_{2}$ coatings were prepared on zinc plates. The influence of layer thickness, porosity, ordered or disordered character of the pore structure, and hydrophobicity was investigated on the permeability and the anti-corrosion behaviour of the coatings. Furthermore, the availability of the pore structure for storage and controlled release of model corrosion inhibitor molecules was also investigated. The permeability of mesoporous $\mathrm{SiO}_{2}$ sol-gel coatings was studied by electrochemical methods (Figure 4). We established that the insulator property of the mesoporous coatings deposited onto polished zinc surfaces reaches that of compact $\mathrm{SiO}_{2}$ coatings. It results also in significant anticorrosion behaviour. The significant anticorrosion property was explained with the better coating ability of the surfactant containing precursor sols. We developed a new method for the storage of water-soluble corrosion inhibitor materials in mesoporous $\mathrm{SiO}_{2}$ sol-gel coatings. The release of the inhibitor molecules occurs only in case of damage of

\footnotetext{
Prepared on the basis of PhD Theses belonging to Emöke Albert's PhD dissertation.
} 
the coating thereby it can result in self-healing property. It was demonstrated experimentally that rendering the surfaces hydrophobic has double advantage: it improves the anticorrosion behaviour and protects the water-soluble inhibitor content of the pore system against the dissolution into the corrosive media from the intact coating (see Figure 4 and Figure 6). ${ }^{9,11,12}$

A novel method was developed for combining the advantageous properties of mesoporous character and periodic surface morphology. Introducing surface patterns in mesoporous $\mathrm{SiO}_{2}$ thin films can have importance in the field of functional coatings, also in antibacterial and anti-corrosion surfaces. The surface morphology at the sub-micrometer scale was prepared by the application of nanosphere lithography together with ion irradiation. For this purpose we applied the ordered Langmuir-Blodgett film of $500 \mathrm{~nm}$ silica particles as mask against $\mathrm{Xe}^{+}$ion irradiation with $200 \mathrm{keV}$ energy. The ions compacted the mesoporous $\mathrm{SiO}_{2}$ coatings where they could get through the openings of the particulate mask, thereby this resulted in evolving surface morphology (Figure 7). The effect of the original nature (ordered or disordered) of the pore system on the modified structure of the samples - a feature yet disregarded - was also studied. We demonstrated that the disordered pore system of the porous $\mathrm{SiO}_{2}$ coatings prepared with the Pluronic PE 10300 molecular template is more resistant against the $200 \mathrm{keV} \mathrm{Xe}^{+}$ion irradiation than the ordered pore structure of sol-gel coatings prepared with cetyltrimethylammonium bromide (Figure 9 and Figure 10). We proved experimentally that besides creating surface morphology, the character of the pore system of $\mathrm{SiO}_{2}$ coatings can be tailored to be interconnected or separated by controlling the ion fluence of the $\mathrm{Xe}^{+}$ion bombardment (Figure 9 and Figure 10). 9,13 